\title{
Babel and Jericho: Architectural Myths for Technological and Psychological Catastrophes
}

\section{Babel y Jericó: Mitos arquitectónicos para catástrofes tecnológicas y psicológicas}

\author{
Derrick De Kerckhove \\ Retired Faculty \\ (French University of Toronto)
}

- Guest paper -

\section{Reception date: 10 December 2016}

To cite this article: De Kerckhove, D. (2017): Babel and Jericho: Architectural Myths for Technological and Psychological Catastrophes, Icono 14, volumen 15 (1), pp. 35-45. doi: 10.7195/ri14.v15i1.1043 


\section{MONOGRÁFICO}

\section{Abstract}

We live in mythical times when the consequences of human social behavior find an expression in large events that mark the century, from the Fall of the Berlin Wall, to that of the towers of the World Trade Centre. Our public figures such as Putin, Erdogan, Bush, both Clintons or Trump are tragic figures occupying the world stage and deciding its destiny. We can seek a pattern in ancient myths to tell modern stories. This paper takes the architectural approach regarding the building or the tearing down of walls, specifically those of Babel, Jericho and the Berlin Wall in order to assess their deeper meaning in terms of the larger picture.

\section{Key Words}

Babel - Jericho- Wall - Berlin - Myth - Catastrophe - Vertical - Horizontal - Literacy Electricity - Explosion - Implosion - Architecture - Pattern

\section{Resumen}

Vivimos en tiempos míticos en los que las consecuencias de comportamiento social humano encuentran expression en acontecimientos que marcan el siglo, de la Caída del Muro de Berlín a la de las Torres del World Trade Centre. Figuras públicas como Putin, Erdogan, Bush, los Clintons o Trump son figuras trágicas que ocupan la primera plana del escenario del mundo y deciden su destino. Los antiguos mitos revelan patrones que vuelven a narrarse en los relatos contemporáneos. Este ensayo toma una perspectiva arquitectónica para explorer la construcción y demolición de muros, como los de Babel, Jericó o Berlín, con el fin de establecdeer su significación en términos más amplios.

\section{Palabras clave}

Babel - Jericó - Muro - Berlín - Mito - Catástrofe - Vertical - Horizontal - Alfabetismo - Electricidad - Explosión - Implosión - Arquitectura - Patrón 


\section{Introduction}

And the Lord came down to see the city and the tower, which the children of men builded. And the Lord said, behold, the people are one, and they have all one language; and this they begin to do: and now nothing will be restrained from them, which they have imagined to do. Let us go down, and there confound their language, that they may not understand one another's speech. (Genesis 11: 5-7)

In the above passage, the oldest book of the Bible acknowledges the limitless, godlike power of language; the first software to create, shape and command matter. It is because they are endowed with language that nothing, except the confusion of languages, can stop the "children of men." Babel and Jericho were both software catastrophes, the first was tragic and the other comic.

The breakdown of communications in Babel addressed a classic - almost Greek - case of hubris: the architects of Babel were punished by the very thing that gave them pride, the universal quality of their language. But the fall of Jericho proposed an alternative: "And it shall come to pass, that when they make a long blast with the ram's horn, and when ye hear the sound of the trumpet, all the people shout with a great shout; and the wall of the city shall fall down flat. And the people shall ascend up every man straight before him." (Joshua 6:5).

The combination of three kinds of sounds was necessary to bring the walls down: the blast from the ram's hom, the sound of the trumpets and the people's great shout. Whatever you make of the prescription, it points to a belief in the ability of sound to pulverize the hardest obstacle, a fact proven by dentistry when it uses sonar teeth cleansing instruments. Indeed, the Berlin Wall could be said to have fallen in part because of music, as when it fell, several rock music concerts had been allowed first on the western side of the wall. Later, on 19 July 1988, 16 months before the Wall came down, Bruce Springteen and the E-Street Ban, played Rocking the Wall, a live concert in East-Berlin, attended by 300,000 in person, and broadcasted on television, a fact that could have been critical in encouraging the people east and west of the wall to bring it down. Springsteen spoke to the crowd in German, saying: "I'm not here for or against any government. I've come to play rock ' $n$ ' roll for you in the hope that one day all the barriers will be torn down." 


\section{MONOGRÁFICO}

McLuhan (1964: 16) had already suggested that the wall would never withstand the pressure applied by the much faster western culture upon the slower eastern one. As a victory of software over hardware, Jericho symbolizes a revolution in physics, a paradigmatic transformation. Today our world is poised between two options, the Babelian disintegration and the Jericho metamorphosis.

\section{Methods}

This paper takes an argumentative semiotic approach regarding the building or the tearing down of walls, specifically those of Babel, Jericho and the Berlin Wall. The discussion helps assess their deeper meaning in terms an architectural debate that opens up to a larger picture. The Babelian metaphor also contributes to trace the mythical moment when the alphabetic man loses connection with Nature, loses connection with the other senses, and declares the domination of the eye over all the other. Via digitalization, all sources of information, including material phenomena and natural processes, including our sensory simulations - for example in virtual reality systems - are homogenized into strings of $0 / 1$ sequences. Part of the "Jericho effect" comes from the ability of an electronic code to infiltrate all substances and translate them into itself.

\section{Discussion}

\subsection{The Literate Revolution: Echo and Narcissus}

Philippe Quéau puts the problem of the modern world squarely into the Babelian purview by suggesting that the issue in Babel was not that the architects merely understood each other, but that they understood each other only too well. (Quéau 1992, 1995). It is the same universalism in today's trends in compatibility, standardization and general convergence in information-processing software that begs comparison with the perils of the accumulated power of a universal language. In spite of much social unrest and a world-wide recession, our relentless technological acceleration may give us the impression that everything is going too well, that we are going too fast towards a destiny that we cannot clearly distinguish, 
as if we were collectively experiencing the rush of a consensual hallucination. We sense the imminence of a catastrophe not necessarily in Biblical terms, but rather in terms of what French philosopher René Thom's (1983) described as a phenomenon that, under the accumulation or acceleration of its own weight and speed, suddenly reaches a point of a catastrophe, which in etymological terms means reversal.

Sudden technological and social acceleration without preparation can indeed lead to disintegration, as both World Wars have amply demonstrated. This surely is the Babel side. However, we are beginning to become accustomed to speed. Our computers are accelerating our physical responses and our reaction time much faster than planes, trains and automobiles ever did. Computers are also combining, unifying, and synchronizing the activities of the global electronic network. We are beginning to perceive this unity as consisting of huge waveforms of electrical currents in electromagnetic fields. This is the soundwave that could bring down all the walls of cities and nation-states. The reversal we should expect is not a disaster, but a transformation - a radically new image of humankind. Humanity, to survive will have to self-organize as a single organism healing itself in zones of stress and strife.

Genesis II does not specify how the Lord confounded language to disperse the people. He could have used writing. The hidden historical ground of the Babel myth many be that Semitic literacy, taking over from Egyptian pictographic orthographies, emphasized the phonological over the ideographic representations of languages, thus emphasizing differences in local dialects and specialized uses of the common language. This hypothesis is all the more probable when one compares the explosive consequences of alphabetic literacy with the power of ideograms to maintain stability in Egypt and China over millennia in spite of vast local disparities in ethnics, dialects and languages.

The alphabet was a powder keg. Among the many consequences of the literate fragmentation, exemplified typically by the invention of the printing press just before the Renaissance, were several explosions; that of Latin as the lingua franca into the vernacular languages, that of the Holy Roman Empire into nation and 
city-states, and that of the medieval religious unity into Reformation and Protestantism. These various explosions generated vicious and protracted wars, just as today, another pair of religious sisters, Shiism and Sunnism, are tearing each other apart and spreading their angst into the rest of the world.

From an architectural point-of-view, perhaps the most consistent effect of the literate revolution in the West was the systematic levelling of vertical structures into horizontal ones. Soon after the printing press began to take hold of the ruling and especially the merchant classes, there was a gradual shift from vertical-feudal hierarchies (God-given power) to horizontal democracies. Few signs are more telling than the profound architectural changes from the High Middle Ages to the late Renaissance. A kind of "horizontal imperative" changed the orientation of building as well as that of thinking. The thinking evolved from a top-down, God-to-man relationship, suffused with mythological context, to a rational earthbound conception exemplified by Voltaire's famous "Il faut cultiver notre jardin" (1931). While the cathedral of Cologne can stand along with all other cathedrals as perfect examples of pre-catastrophic Babelian verticality, built over centuries by the common faith of people who spoke a common vernacular language, the builders of the following era completed their work in their lifetime and adopted the horizontality of the written line and the faithful symmetry of the two pages of an open book.

Paradoxically, notwithstanding all its explosive potential, the invention of the Greek and subsequent alphabets was also a kind of revenge of humankind against Babelian dispersion. It quickly became the "scripta franca" for all Indo-European languages except Russian and associated Slavic tongues. It was the first commoncarrier of information in the West. At the cognitive level, alphabets and print became the common source of all the sensory references of sense-making in the elaboration of meaning. The "common sense" of letters substituted the common sense of integrated sensory experience. Greek mythology said it all. The story of Echo and Narcissus is the story of the fall into silence, which is what happened with alphabetization. The loss of Echo is the loss of the ear. The story, you will remember, is that Narcissus is running after this nymph, and she's playing hard to get. They're having a good time; it is spring and all that. And as he runs after 
her he trips on a branch, and he falls head over a brook, and sees this image of himself. And, as the story says, he falls in love with himself. In "The Gadget Lover: Narcissus as Narcosis," McLuhan made the point very clearly, that it's our narcissistic culture that interprets the myth as if Narcissus fell in love with himself, because we have Freud on our mind. But in fact, because he had never seen himself before, there was no reason for Narcissus to believe that it was himself. He was just totally fascinated by this abstraction of the visual representation of what was, a mere moment before, a multi-media, multi-sensory person.

Meanwhile, Echo is back right behind him thinking, "He's not running after me anymore, not playing". As she calls out after him, her voice bounces off into the distance, hence her name Echo. But Narcissus doesn't listen. He literally loses his hearing. That for me is the mythical moment when the alphabetic man loses connection with Nature, loses connection with the other senses. This is also the kind of attitude that ushers in the Baroque period, where even touch will be simulated by vision in trompe l'oeil and other techniques of illusion. Thus the domination of the eye over all the other senses will be sealed and declared.

Today, the new "common sense" is the digital process. Via digitalization, all sources of information, including material phenomena and natural processes, including our sensory simulations - for example in virtual reality systems - are homogenized into strings of $0 / 1$ sequences. Part of the "Jericho effect" comes from the ability of an electronic code to infiltrate all substances and translate them into itself. Taking example from our most intimate possession, that of our body, it is itself run by electrical impulses that guide synaptic and cellular connections, hence today's growing interest for common, off the street, health measuring sensors that translate electric impulses into data. Electricity springs off from literacy and the alphabet to reverse their effect. This is why we are experiencing both the thrill and the anxiety of acceleration once more.

\subsection{The New Architects}

The new architecture is within and outside the computer; it is made of cable, fiber-optics and hertzian and satellite-supported communication networks. It 


\section{MONOGRÁFICO}

structures the operability of programs and databases. It structures the functioning of State and the Economy. All these systems and networks are tributaries of one single overarching technology: electricity. Electricity is the new single, common language. It is by nature cohesive and implosive, not explosive like the alphabet. By connecting and interconnecting everything electricity brings everything together, even as literacy and print had separated everything in definitions, categories and had stored information in different places.

To be useful and increase their market value, innovative communication technologies such as data networks, videoconferencing systems and myriad applications require maximum interoperability and common standards. In spite of the tendency of system producers and developers to develop proprietary standards, a knee-jerk economic reflex inherited from our Babelian Mechanical Age, the trend is towards integration, and the market itself will eventually wipe out all the players who refuse to play ball. Computers gave us power over the screen and allowed us to personalize information-processing. It is not the world that is becoming global; we are.

That's the good news. The bad news is that every technological innovation brings about an opposite counter-reaction: globalization encourages hyperlocalization, which in many parts of the world, brings social unrest, various patterns of racism and armed conflicts. This is the double-edged Babelian paradox that is present in the redefinition of local identities and allegiances. To the extent that people are globalized, they will also emphasize their local identity all the more. The threat of Babel revisited lurks in the Gulf War, Somalia and the former Yugoslavia, and is made ever more present and evident in the Syrian civil war, the new religious wars of Sunni versus Shia, Jihadism and worldwide terrorism. To say nothing of Brexit and Trumpism.

However, the haunting memory of Babel in the collective unconscious does not necessarily percolate from current issues of political and ethnic strife. We have gone through much more violent and generalized strife without talking about Babel. A Babelian fear may arise from the deeper implications of our new-found power over matter and life, with its social, political, psychological and religious 
consequences. The New Architects are the nuclear power engineers, the molecular engineers, the genetic engineers. The new Tower is a double helix and the new Babelian dream, is the Genome project (the transcription of the entire genetic code) that, with the best intentions in the world, has given genetic engineering an unprecedented power of biological control. In the same manner, Big Data today confer to political and business leaders unlimited power over social control.

Considering what we're doing with the genetic code, we're basically inverting the roles of nature and culture. Until recently, culture was under the domination of nature. You always had to deal with the natural. From the time of the birth control pill until now, we haven't ceased to conquer Nature and to impose the laws of culture on it. Now that we're rewriting the genetic code with cloning and such, the order of precedence has changed. That is one big flip.

Our genetic code is the next level of our universal languages. It should soon become apparent that a certain loss of balance between the powers of nature and those of culture was already built into the phonetic alphabet. The image of the alphabet still resides distantly in our scientific interpretation of the relationships between DNA and RNA. Recombinant genetic engineering allows strings of genetic instructions to be decontextualized from their sources and transplanted into another, different cell, originating from a different individual and, even, from a different species altogether. Likewise, it is the alphabetic principle of recombination, accelerated by digitization that generates innovation in all fields turning the scientific, design and engineering communities into sorcerer's apprentices, that is, people who don't usually know when, where and how to stop the deluge of inventions.

\section{Conclusions}

The fact that we are indeed embarking on a course of total control over nature is abundantly demonstrated by our recent predilection for the vocabulary of artificial reality. Words such as "virtual" reality, "cyber" space, "real" time, "artificial" life, and "endo-" and "nanotechnologies," are enjoying a vertical growth curve. They are clear linguistic symptoms of a "cyborg" trend that seeks to blend organic 
and technical realms. To say nothing about the uncertain and uneasy relationship that ever more invasive technologies enjoy with our bodies. The more pressing issue for the New Architects is that this biotechnical - and soon psycho-technical - realm constitutes a desirable technological support for human destinies. There is absolutely no assurance that the experts have the right context, or indeed, any context at all, to base their research options on. And the fact that medical and pharmaceutical interest groups are already bidding for licensing control over the Genome project's first ascertained discoveries is not destined to reassure anyone. After decades of being hostages to the industrial-military complex, we are threatened with a new kind of seizure of the body politic; that of the industrial-medical complex.

While scientists and technocrats are busy looking to perfect our bodies and minds according to the old model of the Renaissance man, daily technologies are changing us insidiously in a manner that will soon be unrecognizable to obsolete scientific paradigms. The scientific image of the human is that of a perfect machine with replaceable parts. In genetic engineering, the image is only slightly improved. The machine can build itself according to specifications only if you know to modify the programming. The future of health and fitness lies in the concept embodied by the replicant in Ridley Scott's "Blade Runner" (1982). The vicious circle is easy to predict: techno-science will build scientifically balanced organisms to perform scientifically calculated operations to perfection. The computer made flesh. There is no soul to this machine because there is no room for anything but an operational self in the scientific/robotic vision of this being. We certainly need a Babelian catastrophe to avoid that destiny, if it is indeed the direction we are going.

But, in fact, it isn't. Science is no better than science fiction at predicting reality. Scientists, for example, have no idea about the deeper and largely unconscious implications of America's new "political correctness" movement. As a reaction to the threat of an overwhelming control of nature by culture, the tendency called political correctness (PC), which has taken hold in North America like a forest fire and is spreading less easily in Europe, may be an unconscious grass-root response to the fear created by scientific and technological control of what constitutes the 
best image of humankind. Whatever one can object to in the sometimes oppressive attitudes of PC activists and the ominous threats to privacy and civil liberties presented by Data Analytics, it is worth exploring and supporting the notion that each member of society is entitled to equal status in the social setting, irrespective of race, color, religion, gender, state of health, level of education, condition of fortune and class, personal attributes or lack thereof. That may save us from Babel.

\section{References}

Bruce Springteen and the E-Street Ban (1988), “Rocking the Wall Concert” https:// www.youtube.com/watch?v=fK1MwhEDjHg

King James Bible. Genesis 11.5 http://www.kingjamesbibleonline.org/GenesisChapter-11/

King James Bible. "The Walls of Jericho". Joshua 6:5. http://www. kingjamesbibleonline.org/Joshua-Chapter-6/

McLuhan, Marshall (1964), "The Medium is the Message," In Understanding Media: The Extensions of Man. MIT Press, 7-24. http://web.mit.edu/allanmc/www/ mcluhan.mediummessage.pdf

McLuhan, Marshall (1964), "The Gadget Lover: Narcissus as Narcosis," In Understanding Media: The Extensions of Man. MIT Press, 45-53

Quéau, Philippe (1992), “Babel,” Cologne Conference, Nov. 1992 http://new-babel. org/PDF/Babel_Programme_final.pdf

Quéau, Philippe. (1995), "Le virtuel, un état du réel, " Virtualité et réalité dans les sciences. Éd. Gilles Cohen-Tannoudji. Paris : Frontières, 61-93.

Scott, Ridley (1982), "Blade Runner." Warnes Bross, Ladd Company. The Shaw Brothers. http://www.imdb.com/title/tt0083658/

Thom, René (1983), Paraboles et catastrophes, Flammarion, Paris.

Voltaire (1931) [1759]. Morize, André, ed. Candide: ou, L'optimisme; édition critique avec une introd. et un commentaire par André Morize. Paris. 